\title{
Volume Transmission of Substance $P$ in Striatum Induced by Intraplantar Formalin Injection Attenuates Nociceptive Responses via Activation of the Neurokinin 1 Receptor
}

\author{
Yoki Nakamura ${ }^{1}$, Hiroki Izumi ${ }^{1}$, Takumi Shimizu ${ }^{1}$, Kazue Hisaoka-Nakashima $^{1}$, Norimitsu Morioka $^{1}$, \\ and Yoshihiro Nakata ${ }^{1, *}$ \\ ${ }^{1}$ Department of Pharmacology, Graduate School of Biomedical \& Health Sciences, Hiroshima University, \\ Hiroshima 734-8553, Japan
}

Received September 28, 2012; Accepted January 28, 2013

\begin{abstract}
To clarify a role of substance P (SP) in an endogenous pain control mechanism involving the rat striatum, striatal SP release was measured over time by microdialysis following intraplantar injection of $0.4 \%$ formalin. A slow-onset but significant increase of SP and neurokinin 1 receptor (NK1R) internalization in the contralateral striatum were observed following the second phase of formalin-induced nociceptive behaviors. Moreover, $60 \mathrm{~min}$ after formalin injection, preprotachykinin-A, the SP mRNA, and the immediate early gene cFOS were upregulated in the contralateral striatum. Continuous infusion of SP into the striatum by reverse microdialysis attenuated formalin-induced second phase, but not the first phase, nociceptive behaviors, and hind paw mechanical allodynia. Moreover, these anti-nociceptive effects of SP were completely inhibited by co-treatment with the NK1R antagonist CP96345. Acute microinjection of SP, however, at a dose that was similar to the total dose of SP continuously infused into the striatum, did not affect formalin-induced nociceptive behaviors. These data indicate that striatal NK1R activation leads to pain suppression rather than facilitation. Furthermore, volume transmission of SP in the striatum appears to be indispensable in the mechanism of pain control. Modulation of striatal NK1Rs could prove to be a useful method of inducing analgesia.
\end{abstract}

[Supplementary Figure: available only at http://dx.doi.org/10.1254/jphs.12218FP]

Keywords: formalin, neurokinin 1 receptor, striatum, substance P, volume transmission

\section{Introduction}

The striatum is a major target of the basal ganglia and plays critical roles in motor functioning. In rodents, the majority $(95 \%)$ of neurons in the striatum are GABAcontaining medium spiny neurons (MSNs) and comprised of two subpopulations that form two main efferent pathways $(1-3)$. The MSNs mainly project to the medial globus pallidus and substantia nigra pars reticulata (direct pathway) and co-express the dopamine $\mathrm{D}_{1}$ receptor and substance $\mathrm{P}$ (SP), whereas the striatopallidal MSNs project mainly to the lateral globus pallidus (indirect pathway) and co-express the dopamine $\mathrm{D}_{2}$ receptor and

*Corresponding author. ynakata@hiroshima-u.ac.jp

Published online in J-STAGE on March 20, 2013

doi: $10.1254 /$ jphs.12218FP enkephalin $(4,5)$. The remaining striatal neurons are acetylcholine-containing large spiny interneurons, which express the neurokinin 1 receptor (NK1R) $(1,2,6)$. Previous studies reported that the majority of striatal neurons responded to noxious stimulation $(7-11)$. In addition, an antinociceptive effect has been reported following the modulation of the striatal indirect pathway in the rat $(12-14)$. Thus, the striatum is involved in not only the modulation of motor functioning but also involved in nociceptive processing.

SP is synthesized from preprotachykinin-A (PPT-A) mRNA and its preferred target, the NK1R, is expressed throughout the CNS, including the striatum, substantia nigra, and globus pallidus. Compared with other brain regions, the NK1R is expressed in abundance on striatal neurons $(15-18)$. Recent studies have reported that a majority (around 50\% - 80\%) of patients with Parkinson's 
disease, a neurodegenerative disorder in the basal ganglia, complained of various types of pain such as dystonic, radicular-neuropathic, and central neuropathic pain, which were unassociated with muscle rigidity, a major symptom of Parkinson's disease $(19-22)$. Moreover, SP content was reduced in the striatum and in the cerebrospinal fluid (CSF) of Parkinson's disease patients $(23,24)$. These data suggest SP expressed in the striatum might be involved in endogenous pain modulation. However, the mechanism underlying the antinociceptive effects of SP in striatum is as yet unclear.

In vivo microdialysis has been utilized to sample endogenous substances in the extracellular fluid in specific brain regions under resting and pathological conditions $(25-28)$. In addition, it is also possible to adapt this technique to locally administer substances into the extracellular space through the microdialysis probe (29). This technique has been applied extensively in neurotransmitter research. As SP is not taken up into neurons and glial cells, once released from neurons, $\mathrm{SP}$ is capable of leaving the synapse to stimulate distant, extra-synaptic NK1Rs (volume transmission) $(30,31)$. Therefore, this technique could be suitable for investigating a potential role of striatal SP volume transmission in modulating nociception.

In the current study, to clarify a possible role of striatal SP in nociception, microdialysis techniques were used to both measure SP release and apply SP to the striatum and to investigate NK1R pharmacology in rats using the hind paw formalin test. Following hind paw formalin injection, a biphasic display of pain-related behaviors are expressed over time, an early "acute" phase and a late "tonic" phase. These phases are believed to be mediated by different neurological substrates $(32,33)$. Thus, using the formalin test, it is possible to evaluate whether SP has different mechanistic roles depending on the pain state.

\section{Materials and Methods}

All animal procedures were performed in accordance with the Guidelines for Animal Experimentation, Hiroshima University and reviewed and approved by the Committee of Research Facilities for Laboratory Animal Sciences, Graduate School of Biomedical Sciences, Hiroshima University, Japan.

\section{In vivo microdialysis}

Under sodium pentobarbital anesthesia $(50 \mathrm{mg} / \mathrm{kg}$, intraperitoneal injection), each rat was unilaterally implanted with a microdialysis guide cannula [CG-4, outer diameter (o.d.) of $0.50 \mathrm{~mm}$; Eicom, Kyoto] into the striatum $(0.26-\mathrm{mm}$ caudal to bregma, $4.0-\mathrm{mm}$ lateral to the midline, 7.0-mm below the surface of the skull) (34). After surgery, the rats were individually housed in cages during the recovery period for at least 5 days. Microdialysis experiments were performed in unanesthetized and freely moving rats. Microdialysis probes [dialysis membrane: length, $3.0 \mathrm{~mm}$; o.d., $0.31 \mathrm{~mm}$; internal diameter (i.d.), $0.22 \mathrm{~mm}$; C-M-4-03HP; Eicom] were inserted through the guide cannula and continuously perfused with sterile artificial cerebrospinal fluid (aCSF:7.4 g/L NaCl, $0.19 \mathrm{~g} / \mathrm{L} \mathrm{KCl}, 0.19 \mathrm{~g} / \mathrm{L} \mathrm{MgCl}_{2}$, and $0.14 \mathrm{~g} / \mathrm{L} \mathrm{CaCl}_{2}$ ) at a flow rate of $1 \mu \mathrm{L} / \mathrm{min}$ using a microinfusion pump (Eicom) beginning $1 \mathrm{~h}$ before formalin injection and continuing $4 \mathrm{~h}$ post-formalin injection (total infusion time of $5 \mathrm{~h}$ ). The tip of the microdialysis probe protruded $3.0 \mathrm{~mm}$ from the tip of the guide cannula to reach the striatum. Dialysates were collected every $60 \mathrm{~min}$ in a tube on ice, and subsequent measurements of SP content were performed with a highly sensitive radioimmunoassay procedure. The detection limit of the assay was $10 \mathrm{pg}$ per sample (35).

\section{Formalin test}

Behavioral testing was performed in adult, male Wistar rats (6 weeks of age) after one week of acclimation to the housing facility. Prior to the measurement of formalin-induced nociceptive behaviors, each rat was acclimated in the test cylinder $(30-\mathrm{cm}$ diameter, $30-\mathrm{cm}$-high) for $30 \mathrm{~min}$. The rats were then given an intraplantar (i.pl.) injection of $0.4 \%$ formalin $(200 \mu \mathrm{L})$ into the hind paw contralateral to the implanted cannula. The time spent displaying nociceptive behaviors such as lifting, licking, and hind paw biting was recorded (in seconds) for each 5-min period for $120 \mathrm{~min}$ postformalin injection. To determine if local anesthetic block would affect striatal SP-NK1R neurotransmission, in some rats, pretreatment with lidocaine $(20 \mathrm{mg} / \mathrm{mL}$, $100 \mu \mathrm{L}$, i.pl.) was performed $30 \mathrm{~min}$ before formalin injection.

In a subset of formalin-injected rats, edema of the injected hind paw and withdrawal thresholds were assessed with calibrated calipers and von Frey filaments, respectively. The dorsal plantar paw thickness was measured to $0.01 \mathrm{~mm}$. The plantar surface of the hind paws was probed with a von Frey monofilament (Natsume Seisakusho Co., Tokyo) starting with a filament that exerts a force of $0.16 \mathrm{~g}$. When the animal responded to the filament (which included lifting and licking of the hind paw), the next lower force von Frey filament was used. Each hind paw was tested three times. If the animal did not respond, the next higher force von Frey filament was applied. Paw edema and mechanical withdrawal threshold were defined as the percent compared with the baseline value (prior to formalin 
injection). Paw thickness and mechanical threshold were measured 120 min after formalin injection.

\section{Immunohistochemistry}

Under sodium pentobarbital anesthesia $(50 \mathrm{mg} / \mathrm{kg}$, i.p.; Dainippon Sumitomo Pharma, Osaka), rats were transcardially perfused with $50 \mathrm{~mL}$ of saline followed by $150 \mathrm{~mL}$ of freshly prepared $4 \%(\mathrm{w} / \mathrm{v})$ paraformaldehyde in $0.1 \mathrm{M}$ phosphate buffer $(\mathrm{pH}=7.4)$. The brains were quickly removed and postfixed in the same fixative solution for three days at $4^{\circ} \mathrm{C}$ and then cryoprotected overnight in $30 \%(\mathrm{w} / \mathrm{v})$ sucrose in $0.1 \mathrm{M}$ phosphate buffer at $4^{\circ} \mathrm{C}$. Tissues were embedded in Tissue-Tek OCT compound 4583 (Sakura Finetech, Tokyo) and frozen in liquid nitrogen, cut serially $(20-\mu$ m-thickness $)$ in a cryostat, and sections were collected onto glass slides (MAS-GP type A; Matsunami Glass, Osaka). After slides were dried at room temperature, tissue sections were processed for double-labeling immunohistochemistry for the NK1R and NeuN (a marker for neurons). The tissue sections were rinsed with phosphatebuffered saline, incubated in a blocking solution of $10 \%$ goat serum, $3 \%$ bovine serum albumin, $0.1 \%$ Triton $\mathrm{X}$, and $0.05 \%$ Tween-20 in phosphate-buffered saline for 2 $\mathrm{h}$ at room temperature and then incubated with a mixture of rabbit anti-NK1R antibody $(1: 1000)$ and mouse anti-NeuN antibody $(1: 1000)$ for $72 \mathrm{~h}$ at $4^{\circ} \mathrm{C}$, followed by the corresponding secondary antibodies (1:200) conjugated with either Alexa 488 or 555 for $2 \mathrm{~h}$ at $4^{\circ} \mathrm{C}$ in a dark chamber. The sections were then extensively washed in phosphate-buffered saline and then coverslipped. Sections were examined with a BZ-9000 Biorevo all-in-one fluorescence microscope (Keyence, Elmwood Park, NJ, USA).

The immunogen for the current NK1R antibody corresponded to the C-terminus (amino acids $393-407$ ) of the rat NK1R and has been used in immunocytochemistry and western blotting elsewhere $(36,37)$. Other studies that used a similar antibody that recognizes the C-terminus (393 - 407) of the NK1R have demonstrated robust immunostaining of neuronal dendrites and soma and no immunostaining observed in glia (38). In addition, NK1R internalization is visible using antibodies that were raised against the C-terminus $(393-407)$ (39).
To confirm that the primary NK1R antibody is selective for the C-terminus $(393-407)$ of the NK1R, the antibody was preabsorbed with peptide $(10 \mu \mathrm{g} / \mathrm{mL})$ and rat striatum was immunostained with preabsorbed antibody. There was a lack of NK1R immunostaining with preabsorbed antibody (Supplementary Fig. 1, available in the online version only). Also, to verify that the secondary antibody did not nonspecifically label tissues, the primary antibody was omitted in the immunostaining protocol. No immunostaining was observed with the omission of primary antibody (Supplementary Fig. 1).

\section{Western blot analysis}

For western blot analysis, rats were deeply anesthetized, the brains rapidly removed and the striatum dissected. The lysates from striatum were processed for western blot analysis as previously described (40). Forty $\mu \mathrm{g}$ of total protein was used to detect individual proteins. Blots were incubated in primary antibodies against the NK1R (1:5000) and $\beta$-action $(1: 10,000)$. Horseradish peroxidase-conjugated anti-rabbit secondary antibodies (1:2500) were used for chemiluminescence detection according to the manufacturer's instructions. The specific bands of NK1R and $\beta$-actin were detected at position of 46 and $42 \mathrm{kDa}$, respectively.

\section{Real-time PCR analysis}

cDNA synthesized using $0.6 \mu \mathrm{g}$ of total RNA in each sample were subjected to real-time PCR assay with each specific primer and Express $\mathrm{SYBR}^{\circledR}$ Green $\mathrm{ER}^{\mathrm{TM}} \mathrm{q}$ PCR Supermix (Invitrogen, Burlington, ON, Canada). The sequences of the primers are indicated in Table 1. Realtime PCR assays were conducted using a DNA engine Opticon 2 real-time PCR detection system (Bio-Rad, Tokyo). The three-step amplification protocol consisted of $3 \mathrm{~min}$ at $95^{\circ} \mathrm{C}$ followed by 40 cycles at $95^{\circ} \mathrm{C}$ for 15 seconds, $60^{\circ} \mathrm{C}$ for 30 seconds, and $72^{\circ} \mathrm{C}$ for 30 seconds. RNA quantities of the target genes were calculated by the $\mathrm{Ct}$ method. The $\mathrm{Ct}$ values of striatum gene amplification were normalized to those of glyceraldehyde-3phosphate dehydrogenase (GAPDH) amplification. The striatal mRNAs levels were defined as the percent compared with the values from striatum ipsilateral to the formalin-injected hind paw.

Table 1. Primer sequences of real-time PCR of striatum gene

\begin{tabular}{lll}
\hline & Forward primers $\left(5^{\prime} \rightarrow 3^{\prime}\right)$ & Reverse primers $\left(5^{\prime} \rightarrow 3^{\prime}\right)$ \\
\hline$P P T-A$ & GGTGCCAACGATGATCT & GCATCCCGTTTGCCCATT \\
$c F O S$ & CTTTGCCCAAACCACGAC & CTGCGCAAAAGTCCTGTG \\
$P P E$ & ACAACCGTGCGAAAGATAGC & TTCTCATGAAGCCCCCATAG \\
$G A P D H$ & AGCCCAGAACATCATCCCTG & CACCACCTTCTTGATGTCATC \\
\hline
\end{tabular}




\section{Drug application via microdialysis or single injection}

SP and the NK1R antagonist CP96345 were administered into the striatum via the dialysis probe at a rate $1 \mu \mathrm{L} / \mathrm{min}$ beginning $1 \mathrm{~h}$ before formalin injection and continued $2 \mathrm{~h}$ post-formalin injection (total infusion time of $3 \mathrm{~h}$ ). Different concentrations of SP and CP96345 were administered in a cumulative fashion. The drug concentration in the tissue after infusion is diluted about 100 times lower than what is in the microdialysis probe because of the gradient of drug across the dialysis membrane, and subsequent diffusion into the tissue $(41-45)$. Drugs were dissolved in aCSF on the day of the experiment at a concentration of 100 -fold higher than what will be used. For acute microinjection, an injection cannula (length, $5.0 \mathrm{~mm}$; o.d., $0.66 \mathrm{~mm}$; i.d., $0.53 \mathrm{~mm}$ ) was inserted into the guide cannula (the injection cannula protruded $4.0 \mathrm{~mm}$ beyond the tip of guide cannula). Pretreatment with drugs by microinjection was performed $5 \mathrm{~min}$ before formalin injection and at rate of $1 \mu \mathrm{L} / \mathrm{min}$ in a total volume of $1 \mu \mathrm{L}$.

As far as the distribution of drug infused via microdialysis in tissue, a recent study suggests that the distribution is limited to a distance of up to about $1 \mathrm{~mm}$ around the tip of the microdialysis probe (29). The area of distribution in the striatum was also confirmed by perfusing dye into the striatum for $3 \mathrm{~h}$, and perfusion with SP into striatum had no effect on NK1R internalization in rat frontal motor cortex (data not shown). Thus, drug application into the striatum by reverse microdialysis in the current study was strictly limited to the striatum.

\section{Histology}

Following behavioral assessment, the locations of the microdialysis probes were histologically verified (Fig. 1B). For the microinjection cannula, $0.1 \%$ bromphenol blue was injected into the cannula and the brain was dissected. The presence of dye in the striatum confirmed proper placement of the guide cannula. Successful location of the probe in the striatum was determined based on the region defined by a brain atlas (34).

\section{Materials}

Anti-mouse IgG horseradish peroxidase-linked antibody (Cat. \#7074S, Lot. \#H0111) and anti-rabbit IgG horseradish peroxidaselinked antibody (Cat. \#7074S, Lot. \#C2812; Cell Signaling Technology, Beverly, MA, USA); goat anti-rabbit IgG antibody (Alexa Fluor 555, Cat. \#A-21428, Lot. \#853493) and goat anti-mouse IgG antibody (Alexa Fluor 488, Cat. \#A-11001, Lot. \#877595; Invitrogen); anti-mouse NeuN antibody (Cat. \#ABN78, Lot. \#LV1825845; Millipore Corporation, Bedford, MA, USA); [ ${ }^{125} \mathrm{I}_{-}$Try $\left.^{8}\right]$-SP $(81.4 \mathrm{TBq} / \mathrm{mmol}$; New England
Nuclear, Boston, MA, USA); bacitracin, bovine serum albumin and captopril (Nissui, Tokyo); SP (Peptide Institute, Inc., Osaka); CP96345, a NK1R antagonist (Pfizer Central Research, Groton, CT, USA); phosphoramidon (Promega, Madison, WI, USA); anti-rabbit NK1R antibody (Cat. \#S8305, Lot. \#084K4845), antimouse $\beta$-actin antibody (Cat. \#A5441, Lot. \#055K4854), formaldehyde and lidocaine (Sigma Aldrich Co., St. Louis, MO, USA). All other reagents were of the highest purity available from commercial sources.

\section{Statistical analysis}

Values are expressed as mean \pm S.E.M. Comparisons of paw edema and expression of the striatal mRNAs were performed using Student's $t$-test. The data from the formalin test and in vivo microdialysis data were analyzed using two-way analysis of variance (ANOVA) for repeated measures (treatment $\times$ time) followed by the Tukey-Kramer test for post hoc comparisons, while data from the other experiments (comparisons between treatments) were analyzed using a one-way ANOVA followed by the Tukey-Kramer test for post hoc comparisons. A probability value (p) of less than 0.05 was considered to be statistically significant.

\section{Results}

Intraplantar injection with formalin evokes SP release in the rat striatum

Radioimmunoassay (RIA) was used to quantify the amount of SP by in aCSF from the outflow of the microdialysis probes. The perfusion rate was set to $1 \mu \mathrm{L} / \mathrm{min}$ and a total volume of $60 \mu \mathrm{L}$ over 60 min was collected. SP collected under basal conditions was consistently detected in the striatum $(29.18 \pm 6.72 \mathrm{pg}$ per $60 \mathrm{~min}$ sample). Even with the use of a dialysis membrane with a high molecular weight cut-off (approximately 30,000 daltons), recovery of SP from extracellular fluid in the rat striatum was $0.28 \% \pm 0.04 \%$ using the current experimental method (Fig. 1C).

A biphasic response to hind paw formalin injection was observed, an "acute" and "tonic" phase, characterized by nociceptive behaviors, including lifting, licking, and biting of the hind paw. The duration of nociceptive behaviors evoked by formalin over time was significantly greater than that evoked by hind paw saline injection $\left(F_{1,96}=873.25, P<0.001\right.$, two-way ANOVA for repeated measures; Fig. 2A). Moreover, hind paw formalin injection significantly increased paw size, compared with saline injection (basal paw thickness: $4.4 \pm 0.1 \mathrm{~mm}$, $P<0.05$, Student's $t$-test; Fig. 2B).

Hind paw formalin injection produced a significant increase in extracellular SP levels $(206.37 \% \pm 34.22 \%$ 


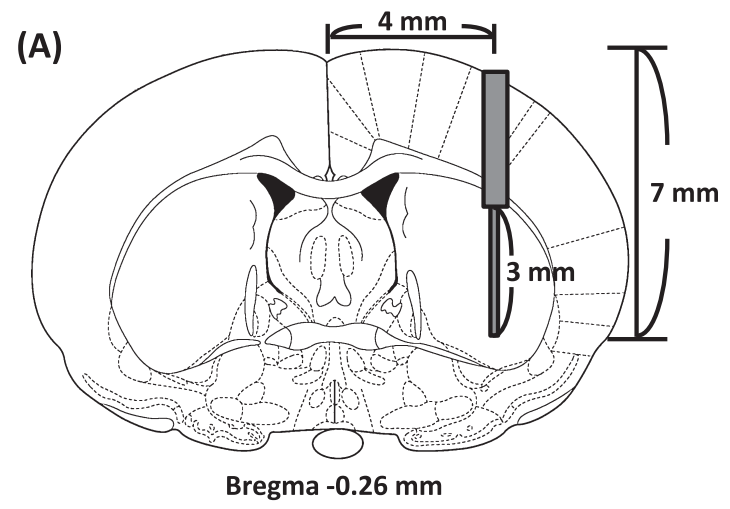

(B)

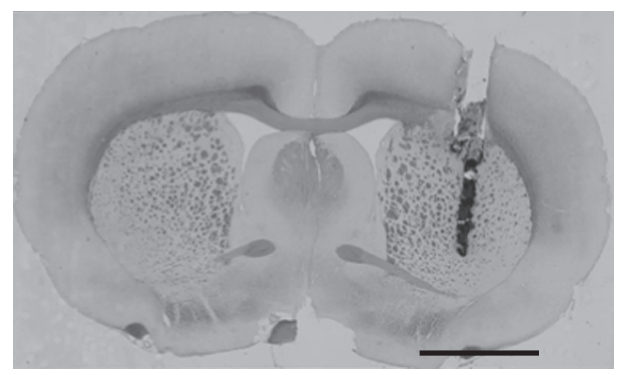

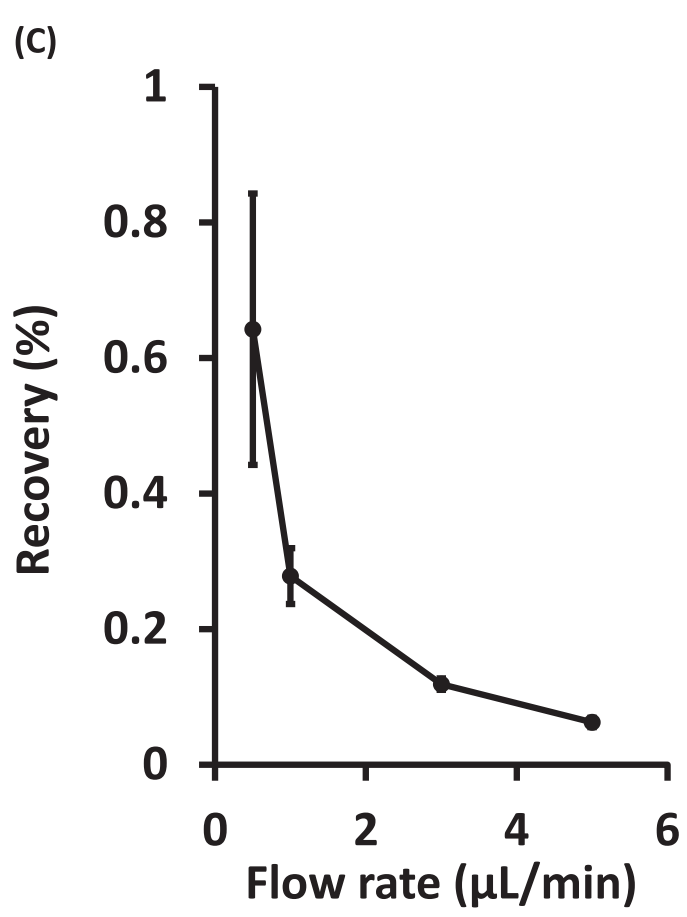

Fig. 1. Brain section and in vitro percent recovery. A schematic drawing (A) and a representative photomicrograph of a coronal brain section (B) showing the localization of the tip of the microdialysis probe membrane within the striatum (34). All microdialysis probes presented an active length of $3 \mathrm{~mm}$ within the striatum. Stereotaxic coordinates of the striatum were determined according to Paxinos and Watson (34): 0.26-mm caudal to bregma, 4.0-mm lateral to the midline, 7.0-mm below the surface of the skull. Scale bar is $3 \mathrm{~mm}$. In vitro percent recovery of Substance P (SP) by microdialysis. In vitro recovery of SP via the currently used microdialysis probes (C-M-4-03HP, Eicom) at various flow rates $(0.5-5.0 \mu \mathrm{L} / \mathrm{min})$. These data are from different probes at different flow rates. The probes were submerged in $1 \mu \mathrm{g} / \mathrm{mL}$ SP (in $0.1 \%$ bovine serum albumin-aCSF, $\mathrm{n}=3$ ) contained in in 1.5 -mL polypropylene tubes. SP content was determined by radioimmunoassay. Experiments were performed at $37^{\circ} \mathrm{C}$. Data are expressed as the mean \pm S.E.M., $\mathrm{n}=3$ /group.

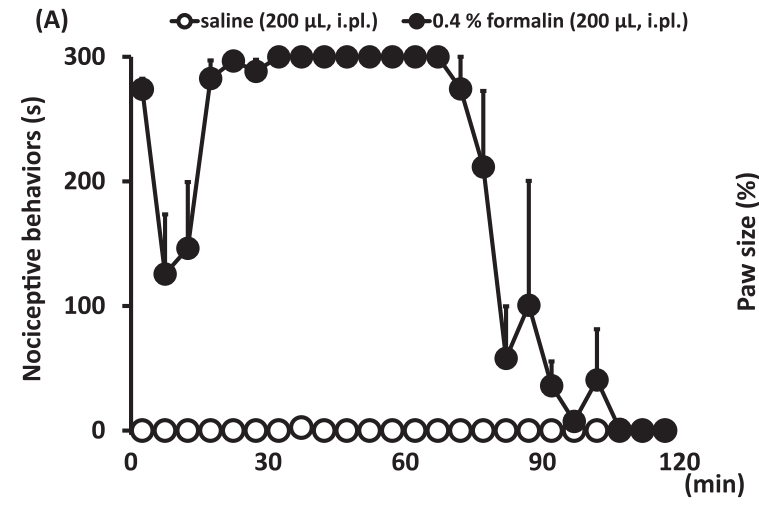

over basal levels $)$ in the contralateral striatum $\left(F_{1,45}=\right.$ 4.64, $P<0.05$, compared with saline-treated rats, twoway ANOVA for repeated measures), but not the ipsilateral striatum $\left(F_{1,35}=1.03, P>0.05\right.$, compared with saline-treated rats, two-way ANOVA for repeated measures), during the period between $2-3 \mathrm{~h}$ after formalin injection (Fig. 3A). The increase in extracellular

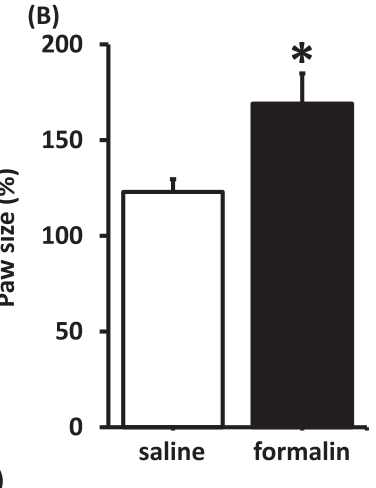

Fig. 2. Formalin-induced nociceptive behaviors and hind paw edema in rats. A) Time course (s) of total duration of nociceptive behaviors (lifting, licking, and biting) following hind paw intraplantar (i.pl.) injection with either $0.4 \%$ formalin $(200 \mu \mathrm{L})$ or saline $(200 \mu \mathrm{L})$. B) Extent of hind paw inflammation following i.pl. injection expressed as percent increase in paw size. Data are expressed as the mean \pm S.E.M. $n=4 /$ treatment group. $* P<0.05$, compared with saline-treated rats (Student's $t$-test).
SP in the contralateral striatum following formalin injection is also significantly higher than SP levels from contralateral striatum from rats that were injected in the hind paw with saline (Fig. 3B). Thus, hind paw injection with saline and, by implication, an acute needle stick alone, is not sufficient to induce a significant release of $\mathrm{SP}$ in the contralateral striatum. 

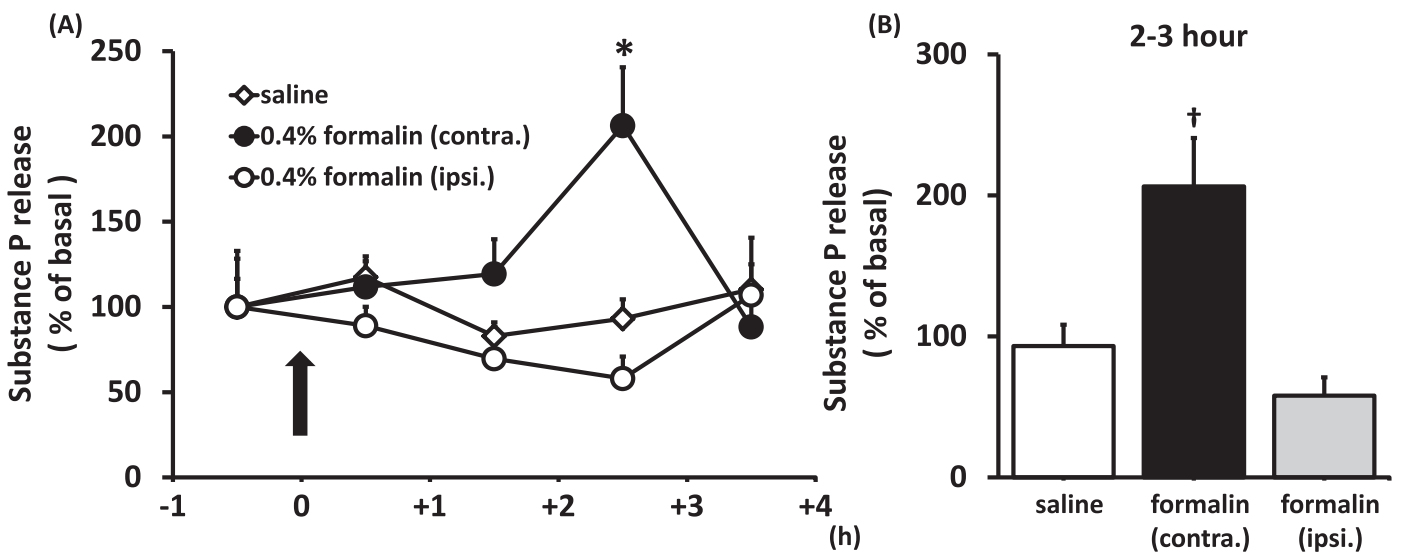

Fig. 3. SP release in the striatum contralateral to the injected hind paw. A) Effects of hind paw $0.4 \%$ formalin $(200 \mu \mathrm{L}$; ipsi.: ipsilateral striatum, $\mathrm{n}=6$; contra.: contralateral striatum, $\mathrm{n}=4)$ or saline $(200 \mu \mathrm{L}, \mathrm{n}=5)$ injection on extracellular SP levels in the striatum over time. The black arrow indicates the time point of intraplantar injection of either formalin or saline. Dialysates were collected every hour. Data are expressed as the percentage change from the basal level of SP. B) Release of SP between $2-3 \mathrm{~h}$ post-formalin injection. Each column represents the percentage of SP over basal SP levels released during the $2-3 \mathrm{~h}$ period. Data are expressed as the mean \pm S.E.M. ${ }^{*} P<0.05$, compared with basal level. ${ }^{\dagger} P<0.05$, compared with the saline group (one-way ANOVA followed by Tukey-Kramer post hoc test).

Robust NK1R internalization was observed following i.pl. injection with formalin. Figure 4, A-E shows representative fluorescence photomicrographs of rat striatal neurons after i.pl. injection with either saline (120 min post-injection, Fig. 4A) or formalin (5, 60, 120 min post-injection; Fig. 4: B - E). Neurons, labeled with $\mathrm{NeuN}$, in the contralateral striatum after injection with saline, showed a distinct ring of immunostaining on the soma, suggesting that NK1Rs were limited externally to the cell membrane (e.g., Fig. 4A). By contrast, in contralateral striatal neurons from rats $120 \mathrm{~min}$ after formalin injection (Fig. 4D), immunostaining on the cell membrane was abolished, indicating NK1R internalization, as observed in previous studies both in vitro and in vivo $(46-49)$. Receptor internalization was not observed, however, 5 and 60 min post-formalin injection (Fig. 4: B, C). Moreover, formalin injection did not induce NK1R internalization in ipsilateral striatal neurons (Fig. 4E). As demonstrated by western blotting, the total amount of NK1R expression in striatum was not changed by i.pl. formalin injection (Fig. 4F). These data indicate that i.pl. formalin injection leads to SP release, as suggested by NK1R internalization, which is limited to the contralateral striatum.

Treatment with formalin induced the expression of PPT-A and $c F O S$ in rat striatum

To determine if the i.pl. formalin-induced increase in extracellular SP was due to increased expression of striatal PPT-A, PPT-A was measured. A significant upregulation of PPT-A mRNA in the contralateral striatum occurred 60 min following hind paw formalin injection $(177.12 \% \pm 22.98 \%, P<0.05$, compared with saline-treated rats; Fig. 5B). Expression of cFOS mRNA, a marker for neuronal activity, also increased in the contralateral striatum $60 \mathrm{~min}$, but not $5 \mathrm{~min}$ after formalin injection $(185.55 \% \pm 32.79 \%, P<0.05$ compared with saline-treated rats; Fig. 5B). By contrast, expression of preproenkephalin (PPE) mRNA, a gene that is abundantly expressed in the striatum, was unchanged by hind paw formalin injection $(89.14 \% \pm 8.47 \%, P>0.05$, compared with saline-treated rats; Fig. 5B). Hind paw saline injection did not significantly affect expression of the mRNAs under investigation.

\section{Influence of lidocaine on formalin-induced SP release in the striatum}

To confirm that the activity of primary afferent nociceptors following hind paw formalin injection is necessary to evoke SP release in the striatum, rats were pretreated with lidocaine $(20 \mathrm{mg} / \mathrm{mL}, 100 \mu \mathrm{L}$ i.pl.). Lidocaine pretreatment significantly suppressed formalininduced SP release in the striatum $\left(F_{1,40}=5.60, P<0.05\right.$, two-way ANOVA for repeated measures; Fig. 6A). The dose of i.pl. lidocaine used was also sufficient to completely inhibit formalin-induced nociceptive behaviors (Fig. 6C).

Pharmacological studies of the striatal NK1R in formalin-induced nociception

The current microdialysis data indicates a continuous rather than acute increase in striatal SP following an 


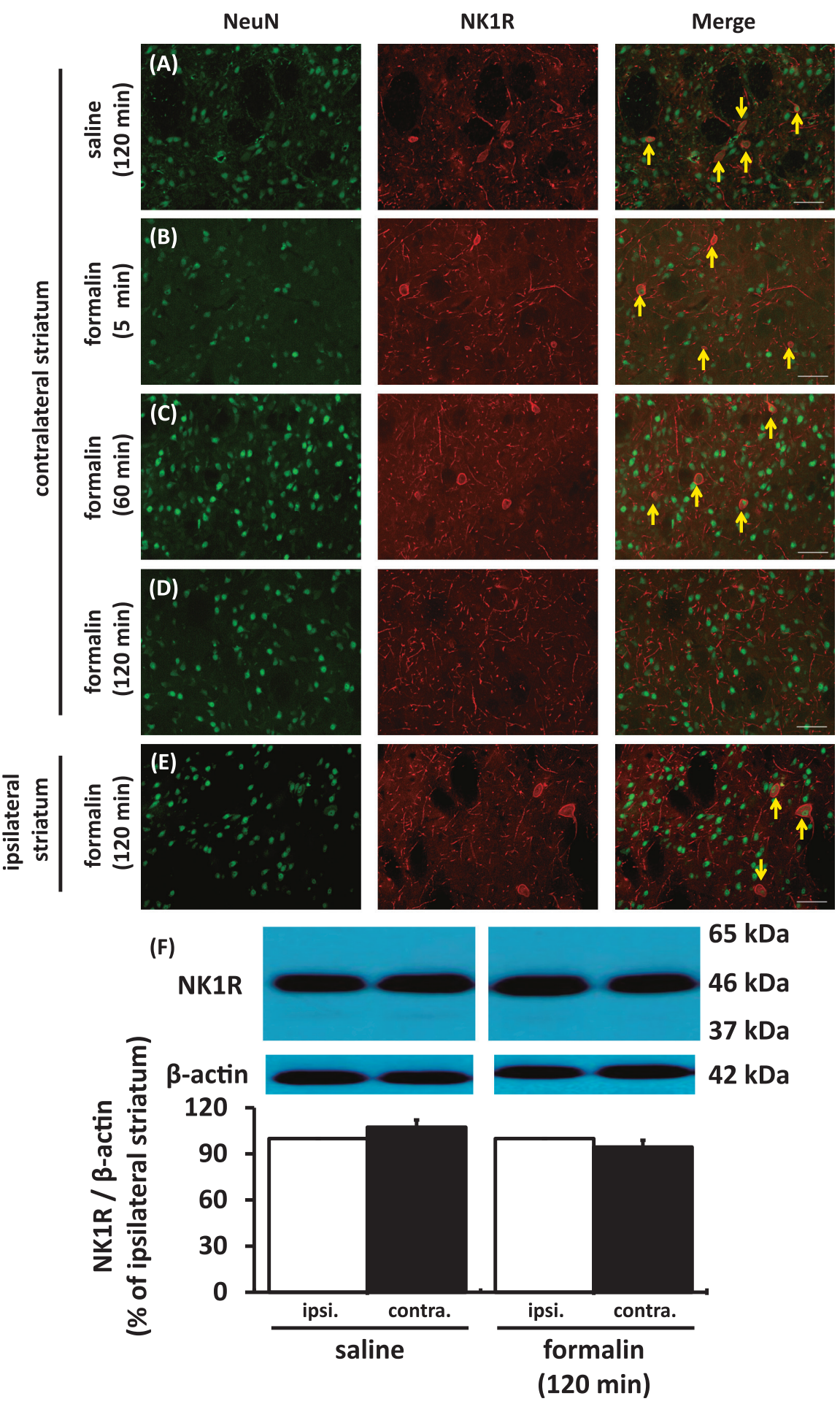

Fig. 4. NK1R internalization in the contralateral striatum induced by intraplantar formalin injection in rats. Striatal sections (implantation coordinates: $0.26-\mathrm{mm}$ caudal to the bregma, $4.0-\mathrm{mm}$ lateral to the midline, $7.0-\mathrm{mm}$ below the surface of the skull) of either saline (120 min)- or formalin (5 - $120 \mathrm{~min})$-injected rats were incubated with anti-NeuN and anti-NK1R antibodies. A) Cell membrane NK1R immunostaining can be observed on striatal neurons of saline-injected rats. B, C, E) Note the presence of NK1R immunostaining surrounding the neuron (cell membrane immunostaining) from formalin (contralateral striatum: 5 and 60 min; ipsilateral striatum: 120 min)-injected rats. D) By contrast, note the lack of NK1 immunostaining surrounding neurons 120 min after formalin injection. The photomicrographs in the 'Merge' column are merged images of the 'NK1R' and 'NeuN' panels. Yellow arrows indicate NK1R-positive neurons without receptor internalization. Scale bar is $50 \mu \mathrm{m}$. F) Comparison of NK1R content in the striatum from saline- and formalin-injected rats measured by western blotting $(\mathrm{n}=3)$. The upper panel indicates $\mathrm{NK} 1 \mathrm{R}$ and the lower panel indicates $\beta$-actin. ipsi.: ipsilateral striatum, contra.: contralateral striatum. 


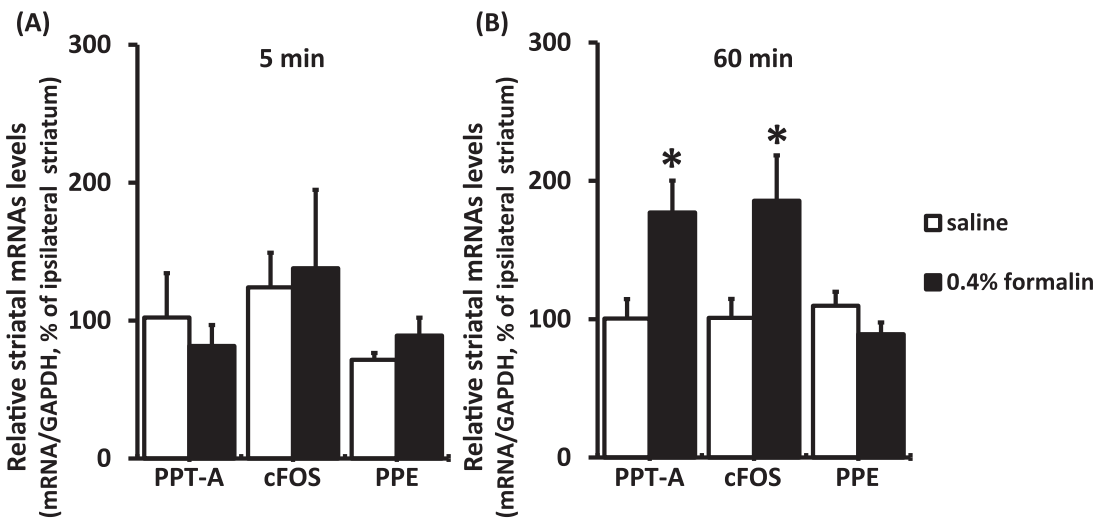

Fig. 5. Effect of intraplantar formalin injection on the expression of mRNAs in the rat striatum over time. Preprotachykinin-A (PPT-A), cFOS, and preproenkephalin (PPE) mRNA were extracted from the striatum from rats injected with either saline or formalin $5 \mathrm{~min}$ (A) and $60 \mathrm{~min}$ (B) following injection. Data are expressed as percent relative to ipsilateral striatum values. Data are reported as the mean \pm S.E.M., $n=4 /$ treatment group. $* P<0.05$, compared with saline-treated rats (Student's $t$-test).
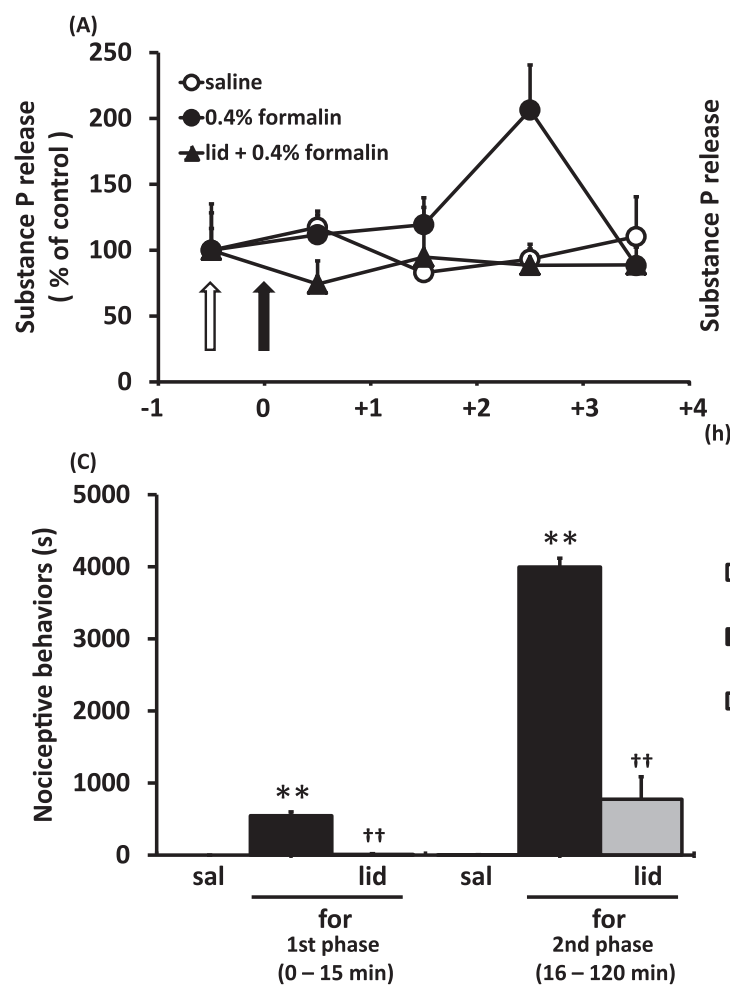

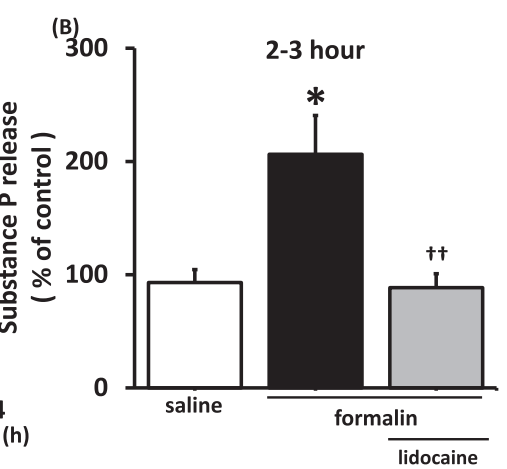

$\square$ saline (i.pl., $200 \mu \mathrm{L}$ )

0.4\% formalin (i.pl., $200 \mu \mathrm{L}$ )

口lidocaine (i.pl., $20 \mathrm{mg} / \mathrm{mL}$ ) $+0.4 \%$ formalin (i.pl., $200 \mu \mathrm{L}$ )
Fig. 6. Effect of lidocaine on the formalininduced SP release in the rat striatum and formalin-induced nociceptive behaviors. A) Thirty minutes prior to hind paw injection with formalin, lidocaine (lid, $20 \mathrm{mg} / \mathrm{mL}$, $100 \mu \mathrm{L}$, i.pl.) was injected (white arrow). The black arrow indicates the time point of i.pl. injection with $0.4 \%$ formalin $(200 \mu \mathrm{L})$. Dialysates were collected once an hour. B) SP levels $2-3 \mathrm{~h}$ following formalin injection. C) Total duration of nociceptive behaviors in the first phase $(0-15 \mathrm{~min})$ and the second phase $(16-120 \mathrm{~min})$ after hind paw injection with either saline (sal, $200 \mu \mathrm{L}$ ) or $0.4 \%$ formalin (for, $200 \mu \mathrm{L}$ ). Data are expressed as the mean \pm S.E.M. $\mathrm{n}=4$ /treatment group. $* P<0.05, * * P<0.01$, compared with saline-treated rats. ${ }^{\dagger} P<0.01$, compared with formalin-treated rats (oneway ANOVA followed by Tukey-Kramer post hoc test). acute hind paw injection of formalin. Thus, the effect of continuous infusion of exogenous SP into the striatum by reverse microdialysis on formalin-induced biphasic nociceptive behaviors was examined. Treatments with regents were administered into the striatum beginning $1 \mathrm{~h}$ before formalin injection and continued 2-h postinjection (a total infusion time of $3 \mathrm{~h}$ ). Interestingly, continuous infusion with SP $(0.4$ or $4 \mu \mathrm{g} / \mathrm{mL}$ in microdialysis fiber, $1 \mu \mathrm{L} / \mathrm{min}$ ) into the striatum significantly reduced the formalin-induced nociceptive behaviors of the second, but not the first, phase $\left(F_{1,312}=91.59\right.$ and $F_{1,312}=55.70$, respectively, $P<0.01$, two-way ANOVA for repeated measures; Fig. 7A). By contrast, continuous infusion with the NK1R antagonist CP96345 (10 or $100 \mu \mathrm{M}$ in the microdialysis fiber, $1 \mu \mathrm{L} / \mathrm{min}$ ) significantly increased formalin-induced nociceptive behaviors in both phases, and, furthermore, prolonged the duration of second phase $\left(F_{1,288}=58.41\right.$ and $F_{1,288}$ $=95.34$, respectively, $P<0.01$, two-way ANOVA for repeated measures; Fig. 7C). Moreover, the effects of SP and CP96345 canceled each other when co-administered $\left(F_{1,312}=4.50, P<0.05\right.$, two-way ANOVA for repeated measures; Fig. 7E).

A single, acute microinjection into the striatum of $1 \mathrm{ng}$ SP, an amount similar that used for continuous infusion, had no effect on formalin-induced nociceptive behaviors 

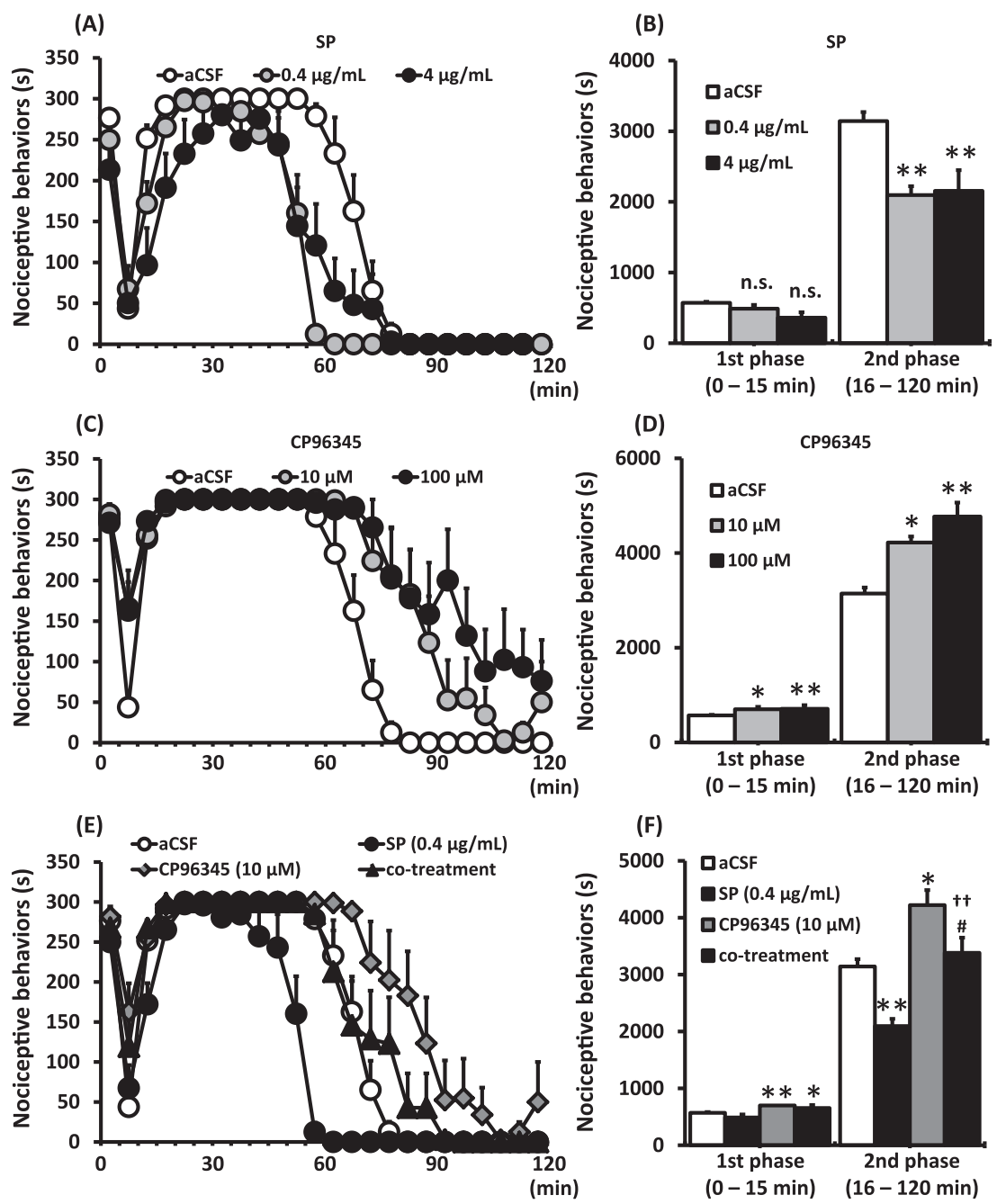

Fig. 7. Effect of continuous infusion of SP and NK1R antagonist into the rat striatum on formalininduced nociceptive behaviors. A, C, E) Formalininduced nociceptive behaviors over time. B, D, F) Total duration of nociceptive behaviors in the first phase $(0-15 \mathrm{~min})$ and the second phase $(16-120$ min) after i.pl. formalin injection. A, B) Treatment with aCSF $(1 \mu \mathrm{L} / \mathrm{min}, \mathrm{n}=7)$ or SP $(0.4,4 \mu \mathrm{g} / \mathrm{mL}$, $\mathrm{n}=7)$. C, D) Treatment with the NK1R antagonist CP96345 $(10,100 \mu \mathrm{M}, 1 \mu \mathrm{L} / \mathrm{min}, \mathrm{n}=6)$ or aCSF. E, F) Treatment with aCSF, SP $(0.4 \mu \mathrm{g} / \mathrm{mL})$, CP96345 $(10 \mu \mathrm{M})$, or co-treatment $(0.4 \mu \mathrm{g} / \mathrm{mL}$ SP and $10 \mu \mathrm{M} \mathrm{CP96345,} 1 \mu \mathrm{L} / \mathrm{min}, \mathrm{n}=7)$. Striatal infusions were started $1 \mathrm{~h}$ before formalin injection and continued $2 \mathrm{~h}$ post-formalin injection (total infusion time of $3 \mathrm{~h}$ ). Data are expressed as the mean \pm S.E.M. n.s., not significant. ${ }^{*} P<0.05$, ${ }^{*} P P<0.01$, compared with aCSF-treated rats. ${ }^{{ }^{H}} P<0.01$, compared with SP-treated rats, second phase. ${ }^{\#} P<0.05$, compared with CP96345-treated rats, second phase (one-way ANOVA followed by Tukey-Kramer post hoc test).

(A)

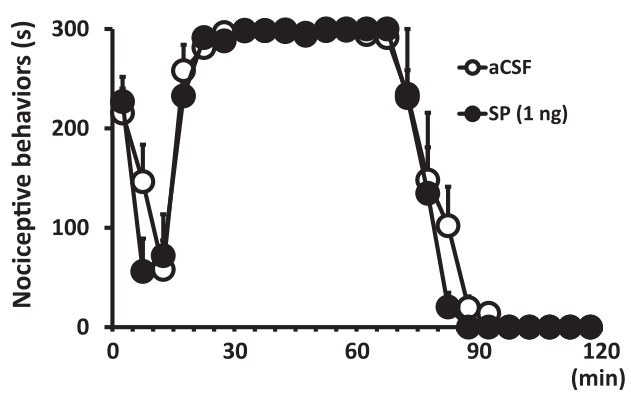

(B)

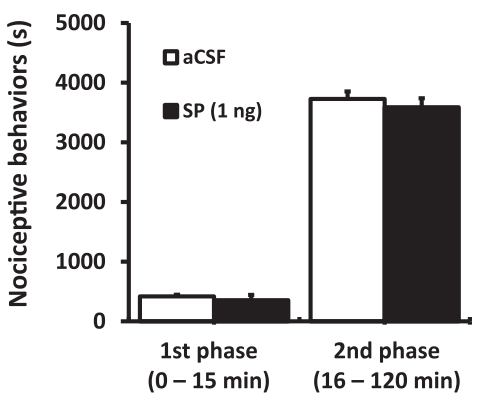

Fig. 8. Effect of an acute injection of SP into the rat striatum on formalin-induced nociceptive behaviors. A) Formalin-induced nociceptive behaviors over time. Either aCSF $(n=3)$ or SP ( $1 \mathrm{ng}, \mathrm{n}=3$ ) were injected into the striatum $5 \mathrm{~min}$ before formalin injection. B) Total duration of nociceptive behaviors in the first $(0-15 \mathrm{~min})$ and second (16 - $120 \mathrm{~min})$ phases after i.pl. injection with formalin. Data are expressed as the mean \pm S.E.M.
$\left(F_{1,96}=1.76, P>0.05\right.$, two-way ANOVA for repeated measures; Fig. 8A).

The effects of continuous infusion of SP into the striatum on other pain-related symptoms caused by formalin, such as mechanical allodynia, and formalininduced inflammation (paw edema) were evaluated
$(50,51)$. Hind paw withdrawal thresholds (pre-formalin injection thresholds: $10.83 \pm 3.49 \mathrm{~g}$ ) were significantly reduced $2 \mathrm{~h}$ after formalin injection (Fig. 9A). Continuous infusion with SP $(0.4 \mu \mathrm{g} / \mathrm{mL}, 1 \mu \mathrm{L} / \mathrm{min})$ significantly increased withdrawal thresholds, thereby reversing formalin-induced mechanical allodynia $(P<0.01$, com- 
(A)

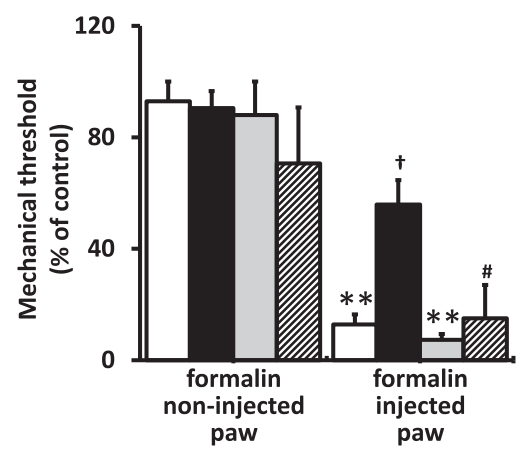

(B)

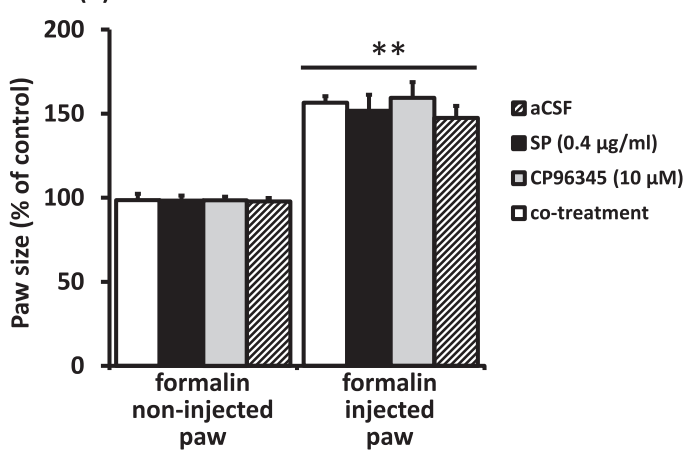

Fig. 9. Effect of continuous infusion of SP and NK1R antagonist into the rat striatum on formalin-induced hind paw mechanical allodynia and edema. Intraplantar injection with $0.4 \%$ formalin $(200 \mu \mathrm{L})$ induced a robust decrease in withdrawal threshold (A) and an increase in paw size (B). Two hours following hind paw formalin injection, withdrawal thresholds to mechanical stimuli and paw edema were measured. Either aCSF $(1 \mu \mathrm{L} / \mathrm{min}, \mathrm{n}=6)$, SP $(0.4 \mu \mathrm{g} / \mathrm{mL}, \mathrm{n}=7)$, NK1R antagonist CP96345 $(10 \mu \mathrm{M}, \mathrm{n}=5)$, or a combination of both $(0.4 \mu \mathrm{g} / \mathrm{mL} \mathrm{SP}$ and $10 \mu \mathrm{M}$ CP96345, $\mathrm{n}=5)$ was administered into the striatum beginning $1 \mathrm{~h}$ prior to formalin injection and continued $2 \mathrm{~h}$ post-formalin injection (total infusion time of $3 \mathrm{~h}$ ). Data are expressed as the mean \pm S.E.M. ${ }^{* *} P<0.01$, compared with the non-injected paw. ${ }^{\dagger} P<0.01$, compared with aCSF-treated rats. ${ }^{\#} P<0.01$, compared with SPtreated rats. (one-way ANOVA followed by Tukey-Kramer post hoc test).

pared with aCSF treatment). Furthermore, simultaneous infusion with CP96345 significantly attenuated the antinociceptive effect of SP $(P<0.01$, compared with SP treatment). Formalin evoked a significant edema in the injected hind paw. Continuous infusion of either SP, CP96345, or a co-treatment into the striatum had no effect on the formalin-induced paw edema (Fig. 9B).

\section{SP-induced NK1R internalization in striatal neurons}

The effect of continuous infusion of SP on NK1R internalization was evaluated. Infusion of aCSF alone had no effect on receptor internalization (Fig. 10A). However, continuous infusion of SP $(0.4 \mu \mathrm{g} / \mathrm{mL})$ into the striatum for $3 \mathrm{~h}$ led to NK1R internalization in striatal neurons (Fig. 10B). Furthermore, co-treatment with CP96345 $(10 \mu \mathrm{M})$ inhibited the SP-induced NK1R internalization (Fig. 10C). The total amount of NK1R protein in rat striatum was not affected, indicating a lack of either receptor degradation or receptor synthesis, by continuous infusion of SP (Fig. 10F).

To confirm that hind paw formalin injection lead to a release of SP in the striatum, CP96345 was infused into the striatum, and then formalin was injected into the hind paw. Figure 10D demonstrates NK1R internalization following hind paw formalin injection in rats infused with aCSF. Continuous striatal infusion with CP96345 prior to formalin injection inhibited the formalin-induced NK1R internalization, confirming that SP is released in the striatum in response to hind paw formalin injection (Fig. 10E).

\section{Discussion}

The current study demonstrated that a noxious chemical stimulus into the hind paw evoked a significant release of SP in the contralateral striatum. Previous studies using microdialysis reported that noxious stimuli induced the release of neurotransmitters, such as dopamine and glutamate, in the brain $(27,52)$. In the current study, a collection time of $60 \mathrm{~min}$ was required to obtain measurable extracellular SP from the striatum. Collection of brain SP is challenging since its relative amount is less than that of other neurotransmitters such as monoamines and amino acids. Agnati et al. hypothesized that there were two distinct types of intercellular communication in the brain- "wiring" and "volume transmission" (53). Monoamines and amino acids are usually involved in wiring transmission, whereas neuropeptides and growth factors are usually involved in volume transmission. In contrast to small-molecule neurotransmitters, the neuropeptides are characterized as having high affinity ( $\mathrm{pM}$ to low $\mathrm{nM}$ ) for their receptors, lacking in a reuptake mechanism to terminate their activity, and having long-lasting (seconds to minutes) modulatory effects on large neuronal-glial cell networks $(30,31)$. SP could be released not only from axon terminals but from anywhere along the surface of SP-containing neurons and potentially reach distant targets sites via diffusion in the extracellular space (volume transmission). The current data demonstrate that peripheral noxious stimulation with formalin evokes activity of peptide containing brain neurons. An additional finding is that continuous 


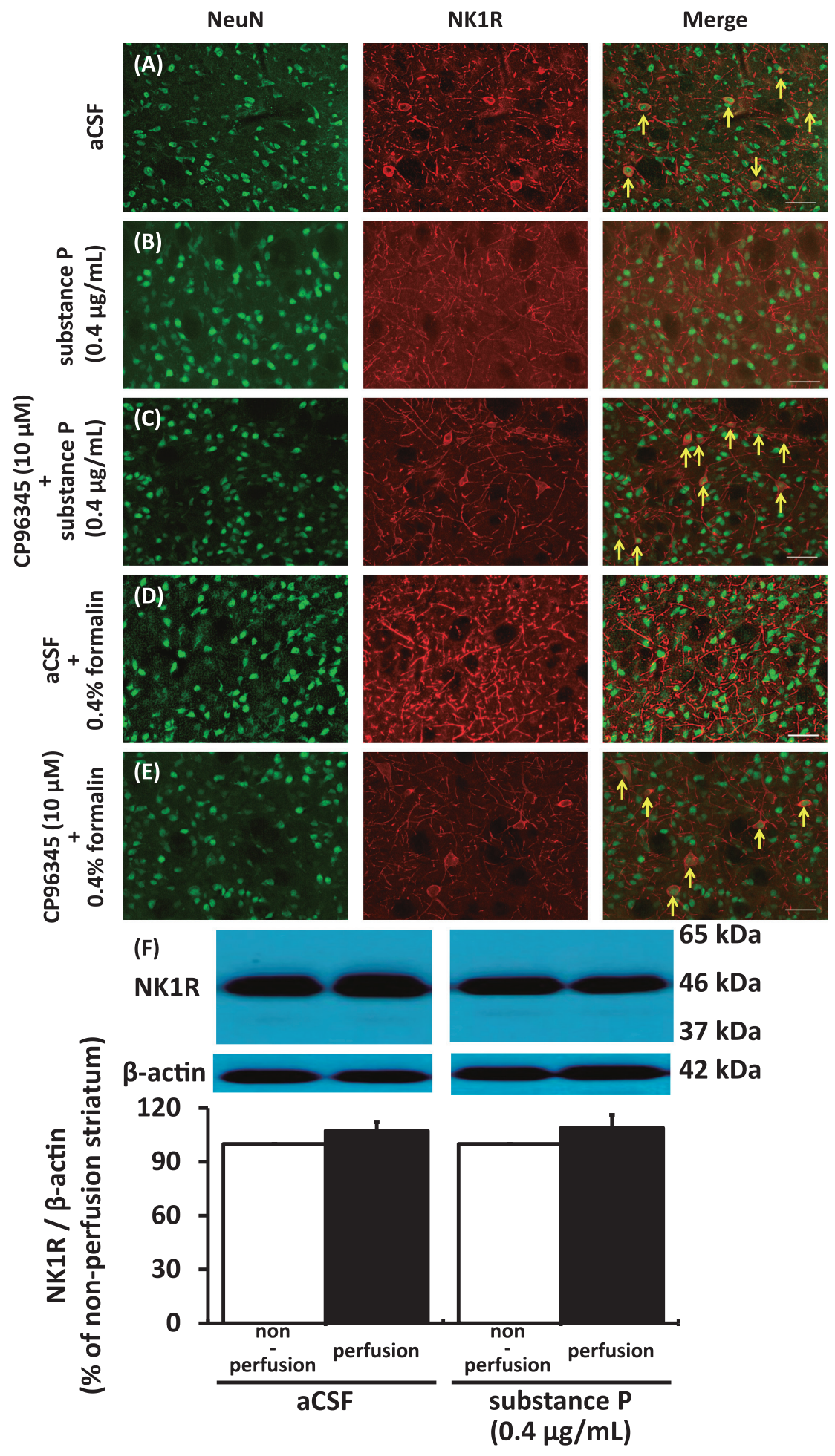

Fig. 10. NK1R internalization in the rat striatum induced by continuous infusion with SP and NK1R antagonist into the striatum. Striatum sections (coordinates from bregma: AP $0.26 \mathrm{~mm}$, ML $4.2 \mathrm{~mm}$, DV $7.0 \mathrm{~mm}$ ) from A) aCSF-treated $(1 \mu \mathrm{L} / \mathrm{min}$, for $3 \mathrm{~h}$ ), B) SP-treated $(0.4 \mu \mathrm{g} / \mathrm{mL}$, for $3 \mathrm{~h})$, and C) co-treated $(0.4 \mu \mathrm{g} / \mathrm{mL}$ SP and $10 \mu \mathrm{M} \mathrm{CP} 96345$ for $3 \mathrm{~h})$ rats were incubated in anti-NeuN and anti-NK1R antibodies. Note the presence of NK1R immunostaining in the cell membrane of neurons in aCSF-treated rats. D) Two hours following hind paw formalin injection, striatal NK1Rs were internalized. E) The NK1R antagonist CP96345 (10 $\mu \mathrm{M}, 1 \mu \mathrm{L} / \mathrm{min}, \mathrm{n}=5$ ) was infused into the striatum $1 \mathrm{~h}$ before hind paw formalin injection and continued $2 \mathrm{~h}$ post-formalin injection (total infusion time of $3 \mathrm{~h}$ ). The photomicrographs in the 'Merge' column are merged images of the 'NK1R' and 'NeuN' panels. Yellow arrows indicate NK1R-positive neurons without receptor internalization. Scale bar is $50 \mu \mathrm{m}$. F) Total amount of NK1R in the striatum measured by western blotting $(n=3)$. The upper panel indicates NK1R and lower panel indicates $\beta$-actin. 
infusion with SP into the striatum reduced diverse painrelated symptoms including formalin-induced hind paw licking and lifting and mechanical allodynia, whereas continuous infusion with a NK1R antagonist increased formalin-induced nociceptive behaviors. The present results confirm, via neurochemistry and gene expression, a pathway that transmits nociceptive signals from peripheral tissues to the contralateral striatum. Furthermore, nociceptive processing, particularly of injury-induced pain, in the striatum significantly involves the tachykinin system, in both the release of SP and activation of the NK1R.

\section{Nociception-evoked SP release in the striatum via} sensory neurons

Nociceptive signals from peripheral tissues enter the dorsal horn via primary afferent sensory neurons, which synapse with nociceptive dorsal horn neurons that in turn cross over the midline and send projections to the supraspinal nuclei by way of the ventrolateral tract (54, 55 ). Functional brain imaging studies, including functional magnetic resonance imaging and autoradiography, documented increased neuronal activity in the striatum contralateral to the injury in animal models of peripheral nerve injury and striatum contralateral to the hind paw injected with formalin $(7-9)$. The current data indicate that an acute injury caused by formalin injection activates supraspinal pain processing in addition to the wellcharacterized activities at the level of primary afferents and the spinal dorsal horn $(56,57)$. By contrast, a brief noxious stimulus (needle stick) is not sufficient to activate these processes and perception of such pain is likely modulated through "normal" mechanisms. Furthermore, the blocking of primary afferent input is sufficient to significantly suppress supraspinal pain processing. In the current study, i.pl. pretreatment with the local anesthetic lidocaine, inhibited both formalininduced nociceptive behaviors and SP release in the striatum. While suppressing pain processing at the level of primary afferents is of clinical significance, few such drugs are available for regular, long-term use in the treatment of chronic pain. Further elaboration of nociceptive processing at other points along the neuraxis could lead to the development of clinically useful analgesics.

The current data suggests that hind paw tissue injury leads to generalized neural activation in the contralateral striatum but not a generalized upregulation of genes. Intraplantar formalin-induced SP release in the striatum was preceded by an up-regulation of PPT-A mRNA. While the immediate early gene cFOS and PPT-A mRNA were increased, PPE mRNA was not increased, despite the fact that PPE mRNA is highly abundant in the striatum (58). Thus, it appears that the effect of formalin on striatal gene expression in the current study could be limited to particular neurotransmitter systems. The neurochemical mechanism that mediates the upregulation in PPT-A in the rat striatum, however, is unclear. One possible mechanism could be the dopaminergic system. Recently, several studies have demonstrated that nociceptive stimuli induced dopamine release in the contralateral striatum in rats, and activation of the dopamine $D_{1}$ receptor modulates the expression of PPT-A mRNA $(52,59,60)$. Thus, these data raise the possibility that i.pl. injection of formalin induced SP release in the striatum through the release of dopamine and subsequent activation of the dopamine $\mathrm{D}_{1}$ receptor and also raises the possibility of an involvement of the striatal dopaminergic system in pain processing. Further evaluation with dopamine receptor antagonists on gene expression and SP release will be needed to confirm this possibility.

It could be argued that internalization as visualized by immunocytochemistry is in fact a degradation process. The current study used western blotting to confirm that neither NK1R degradation nor upregulation occurred following either hind paw formalin injection or continuous SP infusion. Furthermore, the lack of an upregulation of NK1R protein indirectly supports the observation that, despite the increase in cFOS expression in the striatum following hind paw formalin injection, the striatal response to peripheral tissue injury did not generalize to all pain-related molecules, including the NK1R.

\section{Continuous administration of SP in volume transmission mode in the striatum}

The present study used continuous infusion of SP and CP96345 into the striatum by reverse microdialysis. There are a few technical aspects concerning the drugs and drug administration method used that need to be considered. In this study, SP was used rather than other tachykinin peptides, such as neurokinin A and B, which are more selective for the NK1R, because the actions of the endogenous ligand were of interest. While the selective non-peptide NK1R antagonist CP96345 is potent against the NK1R, the actual concentration of the drug delivered by microdialysis into the striatum in the current study is not accurately known $(49,61)$. Thus it is possible that the concentration of CP96345 in the tissue was higher than that of its effective inhibitory constant and that the effects of CP96345 were mediated by off-target activity. Nonetheless, microdialysis offers several advantages, including continued drug delivery and steady-state levels without a volume effect (62). Thus, perfusion via microdialysis is suggested as a method by which to physiologically model volume 
transmission of neuropeptides and growth factors in the brain.

\section{Role of striatal NK1Rs in antinociception}

There is widespread acceptance that SP has positive effects in physiological and pathological conditions, as a neuroprotective and antinociceptive peptide in both in vivo and in vitro assays $(63-65)$. In a recent study, Parenti et al. reported that intracerebroventricular injection of SP reduced hind paw carrageenan-induced mechanical allodynia and heat hyperalgesia, and this antinociceptive effect was prevented by pre-treatment with a selective NK1R antagonist (64). In the current study, continuous infusion of SP into the striatum reduced both formalin-induced nociceptive behaviors and mechanical allodynia, whereas continuous administration with NK1R antagonist increased formalininduced nociceptive behaviors. Furthermore, the SPmediated effects were inhibited with the co-treatment of a NK1R antagonist, confirming a receptor-mediated mechanism. To test whether SP is involved in wired transmission, SP was injected acutely, at a dose similar to the dose of continuously infused SP, into the striatum. A single injection of SP into the striatum had absolutely no effect on formalin-induced nociceptive behaviors, indicating that under physiological conditions, volumerather than wired-transmission underlies the effect of SP in the striatum.

In total, these data indicate that endogenous SP, acting through volume transmission in the striatum, could exert an antinociceptive effect via continuous activation of the NK1R. Conversely, continuous blockade of the NK1R increased formalin-induced nociceptive behaviors in both phases, and prolonged the duration of the second phase. This suggests a tonic release of SP and activation of NK1R in the striatum. While a basal level of immunoreactive SP was detected using microdialysis, widespread NK1R internalization in the uninjured state was not observed. The mechanism that mediates the continuous activation of NK1Rs in the rat striatum is as yet unclear. Previous studies demonstrated that SP increased the release of acetylcholine in the striatum and selectively modulated GABAergic MSN via striatal cholinergic interneurons $(66,67)$. In addition, the antinociceptive effects were mediated by activation of $\mathrm{D}_{2}$ receptors and transmitted through the basal ganglia indirect pathway $(12-14)$. Thus, there is the possibility that SP regulates cholinergic interneurons activity in the striatum and subsequent modulation of the indirect striatal pathway. The region-specific effects of SP could explain the lack of effectiveness observed in the clinical evaluation of NK1 antagonists as analgesics, since paradoxically, NK1R activity in the striatum is necessary for anti- nociception (68).

In conclusion, the current study showed that nociception evoked up-regulation of PPT-A and release of SP in the striatum. Furthermore, continuous activation of NK1R by SP activates an endogenous antinociceptive mechanism. These data demonstrate that the striatum is an important brain area that modulates nociception and suggests that the modulation of the SP-NK1R system in the striatum could prove to be a potent therapeutic target for patients with chronic pain.

\section{Acknowledgments}

This study was supported by a Grant-in-Aid for Scientific Research from the Ministry of Education, Culture, Sports, Science and Technology, Japan and by grants from the Japanese Smoking Research Association. Experiments were carried out using equipment at the Analysis Center of Life Science, Hiroshima University and the Research Center for Molecular Medicine, Faculty of Medicine, Hiroshima University. We also thank Dr. Aldric T. Hama for his critical reading of the manuscript.

\section{References}

1 Tepper JM, Abercrombie ED, Bolam JP. Basal ganglia macrocircuits. Prog Brain Res. 2007;160:3-7.

2 Durieux PF, Schiffmann SN, de Kerchove d'Exaerde A. Targeting neuronal populations of the striatum. Front Neuroanat. 2011;5:40.

3 Kemp JM. Observations on the caudate nucleus of the cat impregnated with the Golgi method. Brain Res. 1968;11: 467-470.

4 Young WS, Bonner TI, Brann MR. Mesencephalic dopamine neurons regulate the expression of neuropeptide mRNAs in the rat forebrain. Proc Natl Acad Sci U S A. 1986;83:9827-9831.

5 Gerfen CR, Engber TM, Mahan LC, Susel Z, Chase TN, Monsma FJ, et al. D1 and D2 dopamine receptor-regulated gene expression of striatonigral and striatopallidal neurons. Science. 1990; 250:1429-1432.

6 Aubry JM, Lundström K, Kawashima E, Ayala G, Schulz P, Bartanusz V, et al. NK1 receptor expression by cholinergic interneurones in human striatum. Neuroreport. 1994;5:15971600.

7 Mao J, Mayer DJ, Price DD. Patterns of increased brain activity indicative of pain in a rat model of peripheral mononeuropathy. J Neurosci. 1993;13:2689-2702.

8 Shih YY, Chang C, Chen JC, Jaw FS. BOLD fMRI mapping of brain responses to nociceptive stimuli in rats under ketamine anesthesia. Med Eng Phys. 2008;30:953-958.

9 Yang PF, Chen DY, Hu JW, Chen JH, Yen CT. Functional tracing of medial nociceptive pathways using activity-dependent manganese-enhanced MRI. Pain. 2011;152:194-203.

10 Chudler EH, Sugiyama K, Dong WK. Nociceptive responses in the neostriatum and globus pallidus of the anesthetized rat. J Neurophysiol. 1993;69:1890-1903.

11 Chudler EH. Response properties of neurons in the caudateputamen and globus pallidus to noxious and non-noxious thermal stimulation in anesthetized rats. Brain Res. 1998;812:283-288.

12 Barceló AC, Filippini B, Pazo JH. The striatum and pain modula- 
tion. Cell Mol Neurobiol. 2012;32:1-12.

13 Gear RW, Levine JD. Rostral ventral medulla cholinergic mechanism in pain-induced analgesia. Neurosci Lett. 2009;464: 170-172.

14 Magnusson JE, Fisher K. The involvement of dopamine in nociception: the role of $\mathrm{D}(1)$ and $\mathrm{D}(2)$ receptors in the dorsolateral striatum. Brain Res. 2000;855:260-266.

15 O'Connor T, O'Connell J, O'Brien D, Goode T, Bredin C, Shanahan F. The role of substance $\mathrm{P}$ in inflammatory disease. J Cell Physiol. 2004;201:167-180.

16 Kraft M, Noailles P, Angulo JA. Substance P modulates cocaine-evoked dopamine overflow in the striatum of the rat brain. Ann N Y Acad Sci. 2001;937:121-131.

17 Pompei P, Severini R, Costa G, Massi M, Fattoretti P, BertoniFreddari C. In situ hybridization analysis of preprotachykinin-A mRNA levels in young and old rats. Brain Res Mol Brain Res. 1999;64:132-136.

18 Severini C, Improta G, Falconieri-Erspamer G, Salvadori S, Erspamer V. The tachykinin peptide family. Pharmacol Rev. 2002;54:285-322.

19 Beiske AG, Loge JH, Rønningen A, Svensson E. Pain in Parkinson's disease: prevalence and characteristics. Pain. 2009; 141:173-177.

20 Boivie J. Pain in Parkinson's disease (PD). Pain. 2009;141:2-3.

21 Ford B. Parkinson disease: pain in Parkinson disease: the hidden epidemic. Nat Rev Neurol. 2009;5:242-243.

22 Letro GH, Quagliato EM, Viana MA. Pain in Parkinson's disease. Arq Neuropsiquiatr. 2009;67:591-594.

23 Fernandez A, de Ceballos ML, Jenner P, Marsden CD. Striatal neuropeptide levels in Parkinson's disease patients. Neurosci Lett. 1992;145:171-174.

24 Pezzoli G, Panerai AE, Di Giulio A, Longo A, Passerini D, Carenzi A. Methionine-enkephalin, substance P, and homovanillic acid in the CSF of parkinsonian patients. Neurology. 1984;34:516-519.

25 Ebner K, Rupniak NM, Saria A, Singewald N. Substance P in the medial amygdala: emotional stress-sensitive release and modulation of anxiety-related behavior in rats. Proc Natl Acad Sci U S A. 2004;101:4280-4285.

26 Singewald N, Chicchi GG, Thurner CC, Tsao KL, Spetea M, Schmidhammer $\mathrm{H}$, et al. Modulation of basal and stress-induced amygdaloid substance $\mathrm{P}$ release by the potent and selective NK1 receptor antagonist L-822429. J Neurochem. 2008;106: 2476-2488.

27 Deyama S, Yamamoto J, Machida T, Tanimoto S, Nakagawa T, Kaneko S, et al. Inhibition of glutamatergic transmission by morphine in the basolateral amygdaloid nucleus reduces paininduced aversion. Neurosci Res. 2007;59:199-204.

28 Gygi SP, Gibb JW, Johnson M, Hanson GR. Blockade of tachykinin NK1 receptors by CP-96345 enhances dopamine release and the striatal dopamine effects of methamphetamine in rats. Eur J Pharmacol. 1993;250:177-180.

29 Ji G, Neugebauer V. Pro- and anti-nociceptive effects of corticotropin-releasing factor (CRF) in central amygdala neurons are mediated through different receptors. J Neurophysiol. 2008; 99:1201-1212.

30 Fuxe K, Dahlström A, Höistad M, Marcellino D, Jansson A, Rivera A, et al. From the Golgi-Cajal mapping to the transmitterbased characterization of the neuronal networks leading to two modes of brain communication: wiring and volume transmission.
Brain Res Rev. 2007;55:17-54.

31 Segawa T, Nakata Y, Yajima H, Kitagawa K. Further observation on the lack of active uptake system for substance $\mathrm{P}$ in the central nervous system. Jpn J Pharmacol. 1977;27:573-580.

32 Tjølsen A, Berge OG, Hunskaar S, Rosland JH, Hole K. The formalin test: an evaluation of the method. Pain. 1992;51:5-17.

33 Shibata M, Ohkubo T, Takahashi H, Inoki R. Modified formalin test: characteristic biphasic pain response. Pain. 1989;38:347-352.

34 Paxinos $\mathrm{G}$, Watson $\mathrm{C}$. The rat brain in stereotaxic coordinates. Compact 3rd edition. Orlando: Academic Press; 1997.

35 Miyano K, Tang H, Nakamura Y, Morioka N, Inoue A, Nakata Y. Paclitaxel and vinorelbine, evoked the release of substance $\mathrm{P}$ from cultured rat dorsal root ganglion cells through different PKC isoform-sensitive ion channels. Neuropharmacology. 2009; $57: 25-32$.

36 Ptak K, Burnet H, Blanchi B, Sieweke M, De Felipe C, Hunt SP, et al. The murine neurokinin NK1 receptor gene contributes to the adult hypoxic facilitation of ventilation. Eur J Neurosci. 2002; 16:2245-2252.

37 Vigna SR, Bowden JJ, McDonald DM, Fisher J, Okamoto A, McVey DC, et al. Characterization of antibodies to the rat substance $\mathrm{P}$ (NK-1) receptor and to a chimeric substance $\mathrm{P}$ receptor expressed in mammalian cells. J Neurosci. 1994;14: 834-845.

38 Liu H, Brown JL, Jasmin L, Maggio JE, Vigna SR, Mantyh $\mathrm{PW}$, et al. Synaptic relationship between substance $\mathrm{P}$ and the substance P receptor: light and electron microscopic characterization of the mismatch between neuropeptides and their receptors. Proc Natl Acad Sci U S A. 1994;91:1009-1013.

39 Mantyh PW, DeMaster E, Malhotra A, Ghilardi JR, Rogers SD, Mantyh CR, et al. Receptor endocytosis and dendrite reshaping in spinal neurons after somatosensory stimulation. Science. 1995;268:1629-1632.

40 Morioka N, Sugimoto T, Tokuhara M, Dohi T, Nakata Y. Noradrenaline induces clock gene Per1 mRNA expression in C6 glioma cells through beta(2)-adrenergic receptor coupled with protein kinase A - cAMP response element binding protein (PKA-CREB) and Src-tyrosine kinase - glycogen synthase kinase-3beta (Src-GSK-3beta). J Pharmacol Sci. 2010;113: 234-245.

41 Han JS, Li W, Neugebauer V. Critical role of calcitonin generelated peptide 1 receptors in the amygdala in synaptic plasticity and pain behavior. J Neurosci. 2005;25:10717-10728.

42 Han JS, Neugebauer V. mGluR1 and mGluR5 antagonists in the amygdala inhibit different components of audible and ultrasonic vocalizations in a model of arthritic pain. Pain. 2005;113: 211-222.

43 Ji G, Neugebauer V. Differential effects of CRF1 and CRF2 receptor antagonists on pain-related sensitization of neurons in the central nucleus of the amygdala. J Neurophysiol. 2007;97: 3893-3904.

44 Li W, Neugebauer V. Block of NMDA and non-NMDA receptor activation results in reduced background and evoked activity of central amygdala neurons in a model of arthritic pain. Pain. 2004;110:112-122.

45 Li W, Neugebauer V. Differential changes of group II and group III mGluR function in central amygdala neurons in a model of arthritic pain. J Neurophysiol. 2006;96:1803-1815.

46 Chen CY, Bechtold AG, Tabor J, Bonham AC. Exercise reduces GABA synaptic input onto nucleus tractus solitarii baroreceptor 
second-order neurons via NK1 receptor internalization in spontaneously hypertensive rats. J Neurosci. 2009;29:2754-2761.

47 Zhang G, Chen W, Lao L, Marvizón JC. Cannabinoid CB1 receptor facilitation of substance $\mathrm{P}$ release in the rat spinal cord, measured as neurokinin 1 receptor internalization. Eur J Neurosci. 2010;31:225-237.

48 Huang PP, Khan I, Suhail MS, Malkmus S, Yaksh TL. Spinal botulinum neurotoxin $\mathrm{B}$ : effects on afferent transmitter release and nociceptive processing. PLoS One. 2011;6:e19126.

49 Nakamura Y, Une Y, Miyano K, Abe H, Hisaoka K, Morioka N, et al. Activation of transient receptor potential Ankyrin 1 evokes nociception through substance $\mathrm{P}$ release from primary sensory neurons. J Neurochem. 2012; 120:1036-1047.

50 Ambriz-Tututi M, Sánchez-González V, Drucker-Colín R. Chromaffin cell transplant in spinal cord reduces secondary allodynia induced by formalin in the rat. Role of opioid receptors and $\alpha_{2}$-adrenoceptors. Eur J Pharmacol. 2011;668:147-154.

51 Bravo-Hernández M, Cervantes-Durán C, Pineda-Farias JB, Barragán-Iglesias P, López-Sánchez P, Granados-Soto V. Role of peripheral and spinal 5-HT(3) receptors in development and maintenance of formalin-induced long-term secondary allodynia and hyperalgesia. Pharmacol Biochem Behav. 2012;101: 246-257.

52 Boutelle MG, Zetterström T, Pei Q, Svensson L, Fillenz M. In vivo neurochemical effects of tail pinch. J Neurosci Methods. 1990;34:151-157.

53 Agnati LF, Fuxe K, Zoli M, Ozini I, Toffano G, Ferraguti F. A correlation analysis of the regional distribution of central enkephalin and beta-endorphin immunoreactive terminals and of opiate receptors in adult and old male rats. Evidence for the existence of two main types of communication in the central nervous system: the volume transmission and the wiring transmission. Acta Physiol Scand. 1986;128:201-207.

54 Almeida TF, Roizenblatt S, Tufik S. Afferent pain pathways: a neuroanatomical review. Brain Res. 2004;1000:40-56.

55 Basbaum AI, Bautista DM, Scherrer G, Julius D. Cellular and molecular mechanisms of pain. Cell. 2009;139:267-284.

56 Dickenson AH, Sullivan AF. Peripheral origins and central modulation of subcutaneous formalin-induced activity of rat dorsal horn neurones. Neurosci Lett. 1987;83:207-211.

57 Puig S, Sorkin LS. Formalin-evoked activity in identified primary afferent fibers: systemic lidocaine suppresses phase-2 activity. Pain. 1996;64:345-355.
58 Gerfen CR, Young WS. Distribution of striatonigral and striatopallidal peptidergic neurons in both patch and matrix compartments: an in situ hybridization histochemistry and fluorescent retrograde tracing study. Brain Res. 1988;460:161-167.

59 Basile AS, Janowsky A, Golembiowska K, Kowalska M, Tam E, Benveniste $\mathrm{M}$, et al. Characterization of the antinociceptive actions of bicifadine in models of acute, persistent, and chronic pain. J Pharmacol Exp Ther. 2007;321:1208-1225.

60 Sin M, Michelhaugh SK, Bannon MJ. D1 receptor regulation of preprotachykinin-A gene by extracellular signal-regulated kinase pathway in striatal cultures. Neuroreport. 2008;19: 187-191.

61 Miyano K, Morioka N, Sugimoto T, Shiraishi S, Uezono Y, Nakata Y. Activation of the neurokinin-1 receptor in rat spinal astrocytes induces $\mathrm{Ca} 2+$ release from IP3-sensitive $\mathrm{Ca} 2+$ stores and extracellular $\mathrm{Ca} 2+$ influx through TRPC3. Neurochem Int. 2010;57:923-934.

62 Stiller CO, Taylor BK, Linderoth B, Gustafsson H, Warsame Afrah A, Brodin E. Microdialysis in pain research. Adv Drug Deliv Rev. 2003;55:1065-1079.

63 Caioli S, Curcio L, Pieri M, Antonini A, Marolda R, Severini $\mathrm{C}$, et al. Substance $\mathrm{P}$ receptor activation induces downregulation of the AMPA receptor functionality in cortical neurons from a genetic model of Amyotrophic Lateral Sclerosis. Neurobiol Dis. 2011;44:92-101.

64 Parenti C, Aricò G, Ronsisvalle G, Scoto GM. Supraspinal injection of Substance P attenuates allodynia and hyperalgesia in a rat model of inflammatory pain. Peptides. 2012;34:412-418.

65 Rosén A, Zhang YX, Lund I, Lundeberg T, Yu LC. Substance P microinjected into the periaqueductal gray matter induces antinociception and is released following morphine administration. Brain Res. 2004;1001:87-94.

66 Anderson JJ, Chase TN, Engber TM. Substance P increases release of acetylcholine in the dorsal striatum of freely moving rats. Brain Res. 1993;623:189-194.

67 Govindaiah G, Wang Y, Cox CL. Substance P selectively modulates GABA(A) receptor-mediated synaptic transmission in striatal cholinergic interneurons. Neuropharmacology. 2010; 58:413-422.

68 Urban LA, Fox AJ. NK1 receptor antagonists - are they really without effect in the pain clinic? Trends Pharmacol Sci. 2000; 21:462-464. 